\title{
FORMATION OF SUSTAINABLE LAND-USE SYSTEMS IN EROSION DANGEROUS LANDSCAPES
}

\author{
Iryna Novakovska ${ }^{1}$, Volodymyr Bulgakov ${ }^{2}$, Semjons Ivanovs ${ }^{3}$, Ilmars Dukulis ${ }^{3}$ \\ ${ }^{1}$ National Aviation University, Ukraine; ${ }^{2}$ National University of Life and Environmental Sciences of \\ Ukraine, Ukraine; ${ }^{3}$ Latvia University of Life Sciences and Technologies, Latvia \\ semjons@apollo.lv, ilmars.dukulis@1lu.lv
}

\begin{abstract}
During the last 50 years the humus content in the arable layer of the soil in the basic agrarian regions of Ukraine (steppe and forest steppe) has diminished by 15-18\%. Optimisation of the structure of land areas and stabilisation of agricultural landscapes should be based on the soil indicators that ensure conservation of land. It has been substantiated that the contour-meliorative system of land use under the conditions of the development of farming enterprises as the main form of the contemporary land system should be modernised. Primary water collectors should be selected as the object of formation of this system. There are proposed new directions of measures to improve the protection of the soil mantle. The results of the conducted investigation will help stop the soil fertility deterioration process because of excessively high share of arable land and disregard of the ecological and agronomic land-use norms. It is prognosticated that the area of the arable land will decrease by $5.1 \mathrm{mln}$. ha, but the area of forests and protective plantations will increase by 2.7 million hectares, reaching the proportion of the territory covered by forests to $22 \%$.
\end{abstract}

Keywords: land resources, land use, ecology, ecological optimisation.

\section{Introduction}

The scarce potential of land as a means of production, impossibility to relocate it, the individualised level of soil fertility in each particular area predetermine the need for preservation of land and soil, ecologisation of the land use, as well as optimisation of the land-use systems [1].

Among the negative processes that reduce the fertility of soils and even lead to the loss of the soil mantle is soil erosion. In Ukraine, since the 1980-ties, a significant amount of work has been done in order to scientifically justify, design and organise economic support and practical implementation of the soil protection system of agriculture. Only general schemes of anti-erosion measures have been developed for 50 regions (9 million hectares), but the land management projects with a contourmeliorative organisation of the territory have been compiled for 2130 farms on the area of 8.2 million hectares [2]. Taking into account this experience, a highly urgent task is to study the contemporary optimisation problems of the land-use system on the principles of its ecological balance with a view to ensure rational use and protection of the land, water and plant resources. The works of V.Dokuchayev, the founder of genetic pedology, made it possible for the scientist-agronomist I. Ovsinsky to develop a system of the surface treatment of soils and band-sown crops at the end of the 19-th century, which was not welcomed in his homeland in Russia, but was successfully introduced in the United States, Canada and Australia [2]. This system is regarded as the starting point for the works to combat soil erosion, to develop an erosion control system in agriculture. Numerous works by domestic and foreign authors are devoted to the study of the use, recovery and protection of the land resources. To them belong publications by A. Kashtanova and M. Zaslavsky [3], F. Morgun, N. Shikuly, A. Tarariko [4], G. Shwebs [5], who made important contribution to the development of scientific fundamentals for the adaptive landscape land-use systems, to introduction of minimised soil cultivation, formation of a contour-meliorative organisation of the territory, application of mathematical simulation of the erosion processes. Large-scale studies (on the assessment of erosion and its simulation, the use of vegetation in soil protection) were carried out by R. Morgan, P. Blaikie, M. Bakker, G. Govers, A. Van Doorn, F. Quetier, D. Chouvardas, M. Rounsevell), Wismeier, Smith, Woodruff, Siddoway; Laflen and Flanagan) [6-8]. The latter scientists developed models for "the management of the soil losses" and "the control of the wind erosion"; they carry out scientific justification for the control of the water erosion forecasting. In the European countries, and especially in the USA, nature protection programmes have been formed (Natura, Conservation Reserve Programme, Grazing Lands Conservation Initiative, Highly Erodible Land).

However, there are not sufficiently studied a number of problems with taking into account the effect of negative processes that cause a decline in soil fertility, with the formation of fundamental principles for the functioning of agrolandscapes under contemporary conditions, with the issues of the 
ecological optimisation of the land-use system. The need to continue research on these problems is quite evident, especially in connection with the climate change and the increasing rate of precipitation.

\section{Materials and methods}

The purpose of this study is to develop main provisions for the optimisation of the land-use systems based on the construction of various models and the formation of agrolandscapes, their analysis, as well as the identification of directions and mechanisms for the improvement of the landscape land management under the conditions of Ukraine. Methodical approaches, based on the foundations of the theory of nature management, erosion and landscape studies are used in this work.

The main elements of optimisation and the land-use systems were considered in a complex and studied using three models (variants) with a different ratio of the area of the cultivated lands and forest areas according to the calculation-variant method. The first model envisaged an increase in the forest area to the European level (30\%) and a corresponding reduction in the arable land area; the second model envisaged formation of the composition of the land areas in a joint complex in accordance with the National Programme; the third one is based on the principle of achieving zero degradation of soil. Indicators of the percentage of arable areas and forests in the analysed territory are also taken into account in the most well-known models, when determining the soil erosion losses both in the Western Europe Revised Universal Soil Loss Equation (RUSLE) [9], and similar studies under the conditions of Ukraine and Moldova in the 1980s [5]. Together with the criteria of precipitation, relief, soil susceptibility to erosion, types of farming, they are also criteria for establishing the level of soil losses to optimise the structure of landscapes and the land use systems. As a base level of the erosion degradation of lands, a $15.4 \mathrm{t} \cdot \mathrm{ha}^{-1}$ intensity indicator of the soil losses is accepted.

When developing a system of measures to improve the contour-meliorative organisation of the territory, calculated methods for quantifying erosion losses of soils, estimating the intensity of erosion, ecological differentiation of lands, the design of forest landscapes and the hydrographical network are applied. When developing a system of measures to improve the contour-meliorative organisation of the territory, there were applied calculation methods for quantitative account of the soil erosion losses, estimation of the erosion intensity, ecological differentiation of areas, designing the forest landscapes and the hydrographical network. The generalisations and recommendations proposed in the work are based on the analysis of information contained in recent-time scientific publications and fundamental works of the domestic and foreign scientists.

The danger of soil erosion ( $S$, years) was determined according to the formula:

$$
S=\frac{H}{P},
$$

where $H$ - mass of the genetic horizon of soils, $\mathrm{t} \cdot \mathrm{ha}^{-1}$;

$$
P \text { - washing soils, a year, } \mathrm{t} \cdot \mathrm{ha}^{-1} \text {. }
$$

Value $S$ indicates in how many years horizon $H$ will be lost. Estimation of the erosion hazard of soils is carried out according to the data contained in Table 1 [14].

Table 1

Rating of the erosion hazard

\begin{tabular}{|c|c|l|}
\hline $\begin{array}{c}\text { Value } \boldsymbol{S}, \\
\text { years }\end{array}$ & $\begin{array}{c}\text { Degree of the soil } \\
\text { erosion hazard }\end{array}$ & \multicolumn{1}{c|}{ Characteristics of the soil erosion hazard } \\
\hline$>1000$ & 1 & There is no soil erosion hazard \\
\hline 600 & 2 & The start of soil erosion is observed \\
\hline 300 & 3 & $\begin{array}{l}\text { A pre-crisis condition of the soil. Erosion processes actually } \\
\text { threaten the preservation of soils. }\end{array}$ \\
\hline 150 & 4 & $\begin{array}{l}\text { A critical condition of the soil. Increased reduction in the } \\
\text { soil depth is observed. }\end{array}$ \\
\hline$<150$ & 5 & $\begin{array}{l}\text { A catastrophic condition of the soil. Conditions arose for } \\
\text { the loss of soil of one generation. }\end{array}$ \\
\hline
\end{tabular}




\section{Results and discussion}

The use and recovery of the soil fertility should be a joint continuous process, and the use and protection of land should be regarded as parts of a complex system of protection and improvement of the environment, as a whole. Creation of stable ecosystems having high self-regulating properties, with optimal ratios of forests, forest plantations, arable lands, meadows, pasture lands, swamps, urbanised territories, a controlled water regime and soil fertility is one of the main tasks of designing agrolandscapes and multicultural territories with the aim of forming stable agroecosystems.

Land protection is a set of legal, economic, organisational and technological measures aimed at the rational use of land. The most important of them are prevention of unjustified retirement of land from the agricultural turnover, ecological optimisation of agrolandscapes, protection of soils from a harmful anthropogenic impact, recovery and raising soil fertility and productivity of the lands from the forest fund.

The basic elements of environmental optimisation of the agrolandscapes and the land-use systems are [9]:

- optimal share of the forest in the territory, which ensures to a great extent the stability of the agroecosystem;

- optimal share of the arable land in the territory;

- a system of protected nature reserves, preservation of the ecological framework;

- preservation of the natural state of the water-swamp territories and construction of buffer water protection bands along small rivers, lakes, reservoirs;

- introduction of a contour-meliorative system of organisation in the territory, including antierosion agrotechnical, forest-meliorative and hydrotechnical methods; application of crop rotations with an ecologically sound structure of the sown areas, anti-erosion technologies of soil cultivation.

In connection with the changes in the climatic conditions, in particular the rising temperature, intensified storm rainfalls and wind, the system of measures for ecological optimisation of the land use should be constantly improved. Analysis of the NOAA satellite data for 1982-2012 confirmed the temperature rise for 2012 in all administrative regions of Ukraine by $1.5-2.0^{\circ} \mathrm{C}$. The complex of antierosion measures should embrace the primary water collectors of water sources as facilities to maintain agro-landscapes and contribute to the improvement of the normative and legal basis for the fight against erosion, especially in connection with the widespread extension of the leasehold land relations in agriculture [11]. The basis for the stabilisation of the land use is restoration of the previously lost correlation between the natural complexes - areas of meadows, pastures, forests, water and sowings. To this end, we have previously discussed three models of ecological optimisation of the land-use systems [11]. The first model provides for the reduction of the areas of arable land by 10 million hectares, the second - by 3.2 million hectares, the third - by 5.1 million hectares, with the simultaneous increase in the area of forests and protective forest plantations, respectively, by $7.5 ; 0.4$; 2.7 million hectares (Table 2).

Prognosticated areas of arable land and forests up to the year 2030

\begin{tabular}{|c|c|c|c|c|c|c|}
\hline \multirow{2}{*}{$\begin{array}{c}\text { Variants } \\
\text { (models) }\end{array}$} & $\begin{array}{c}\text { Current } \\
\text { area, } \\
\text { million ha } \\
(2016)\end{array}$ & $\begin{array}{c}\text { Prognosti } \\
\text { cated } \\
\text { area, } \\
\text { million ha }\end{array}$ & $\begin{array}{c}\text { Prognosticate } \\
\text { d degree of } \\
\text { ploughed } \\
\text { areas, \% }\end{array}$ & $\begin{array}{c}\text { Forests and protective forest plantations } \\
\text { area, } \\
\text { million ha } \\
(2016)\end{array}$ & $\begin{array}{c}\text { Prognostica } \\
\text { ted area, } \\
\text { million ha }\end{array}$ & $\begin{array}{c}\text { Prognosticated } \\
\text { degree of } \\
\text { afforested } \\
\text { area, } \%\end{array}$ \\
\hline Variant I & 32.5 & 22.5 & 37.3 & 10.6 & 18.1 & 30.0 \\
\hline Variant II & 32.5 & 29.3 & 48.5 & 10.6 & 11.0 & 18.4 \\
\hline Variant III & 32.5 & 27.4 & 45.4 & 10.6 & 13.3 & 22.0 \\
\hline
\end{tabular}

The proposal to increase the areas of forests and other forest plantations in the country to $30 \%$ of the entire territory is based on the EU land-use standards, characterised by a $31 \%$ average degree of forests (without Russia). In addition, the reduction of the area of the arable land by 10 million hectares is not justified by the qualitative composition of its soil mantle since only $50 \%$ of these arable lands 
belong to the degraded and poorly productive lands. According to the project of the National Program of the use and protection of land in Ukraine, the area of the forest plantations should increase only by 0.4 million hectares, which will not allow creation of forests on strongly eroded sloping lands (Variant 2). In general, it is planned to reduce the area of the arable land, due to their conservation, by 3.2 million hectares. This will lower the level (the share of arable land) to $48.5 \%$ and will allow the creation of meadows and forests on the most part of the strongly eroded arable land. According to Variant 3 the forecast of the correlation of the arable land and forests was built by us on the basis of the degradation indicators of the soil mantle, that is, the areas of degraded, low-productive and technogenically contaminated soils, subject to conservation (their total area is 5.1 million hectares). It also takes into account to a sufficient degree the economic indicators of management on these soils. It is prognosticated that the area of the arable land will decrease by $5.1 \mathrm{mln}$. ha, but the area of forests and protective plantations will increase by 2.7 million hectares, reaching the proportion of the territory covered by forests to $22 \%$. Optimization of the structure of the land areas, carried out by the linear programming methods, led to the determination of the areas of arable land at the amount of 18.4 million hectares, and the natural forage areas - 18.1 million hectares. This is, correspondingly, by 14 million hectares less, and by 10.3 million hectares more than the current areas of similar areas. Considering that from 1990 to 2016 the livestock population in Ukraine decreased 6.8 times, but the area of natural lands remained during this period at the level of 7.4-7.8 million hectares, it is difficult to agree with the fact that the area of these lands, prognosticated by the methods of programming, 18.1 million hectares ( 2.3 times more than the present one) can be attributed to the optimal one. The erosion losses of soils according to the models of ecological optimisation of the land use systems are: variant I $-10.7 \mathrm{t} \cdot \mathrm{ha}^{-1}$, variant II $-13.9 \mathrm{t} \cdot \mathrm{ha}^{-1}$, variant III $-13.0 \mathrm{t} \cdot \mathrm{ha}^{-1}$. This, respectively, is less than the level of the existing losses by $30.5 \%, 9.7 \%, 15.5 \%$. This decrease in the intensity of erosion is a significant step in achieving a neutral level of erosion degradation of lands in the landscapes [12]. The reliability of the obtained results is confirmed by the data obtained from 6 local territories of Ukraine [11]. When comparing the experimental data by local areas, the coefficient of variation was $18 \%$, which indicates a fairly high accuracy. Among the negative processes, reducing the fertility of soils or leading to the loss of the soil mantle, in general, erosion occupies a special place. The factors determining the origin and development of erosion are the relief (a slope, a slope exposition, its shape), the geological structure of the soil-forming rocks, the physical and chemical properties of the soil, their tolerance to erosion, the climate, the impact of human economic activities. In areas subject to the water or wind erosion, the organisation of the territory should, as a rule, be anti-erosive [3]. The size of the slopes of the land surface, estimated on the basis of the data from the State Land Cadastre of Ukraine, is presented in Table 3.

Distribution of the areas of agricultural land by the size of the slope

Table 3

\begin{tabular}{|c|c|c|c|c|c|c|c|c|}
\hline \multirow{2}{*}{$\begin{array}{l}\text { Size of } \\
\text { the } \\
\text { slope, } \\
\text { deg. }\end{array}$} & \multicolumn{2}{|c|}{ Arable land } & \multicolumn{2}{|c|}{ Perennial plantations } & \multicolumn{2}{|c|}{ Hayfields } & \multicolumn{2}{|c|}{ Pastures } \\
\hline & $\begin{array}{c}\text { Area, } \\
\text { thous. ha }\end{array}$ & $\%$ & $\begin{array}{c}\text { Area, } \\
\text { thous. ha }\end{array}$ & $\%$ & $\begin{array}{c}\text { Area, } \\
\text { thous. ha }\end{array}$ & $\%$ & $\begin{array}{c}\text { Area, } \\
\text { thous. ha }\end{array}$ & $\%$ \\
\hline Up to $1^{\circ}$ & 17471.4 & 55.2 & 386.5 & 44.7 & 1504.4 & 74.1 & 2193.0 & 44.0 \\
\hline $1-2^{\circ}$ & 6938.0 & 21.9 & 178.2 & 20.6 & 106.1 & 5.2 & 470.0 & 9.4 \\
\hline $2-3^{\circ}$ & 3605.1 & 11.4 & 114.4 & 13.2 & 77.8 & 3.8 & 460.7 & 9.2 \\
\hline $3-5^{\circ}$ & 2442.8 & 7.7 & 102.4 & 11,8 & 85.3 & 4.2 & 601.6 & 12.1 \\
\hline $5-7^{\circ}$ & 878.6 & 2.8 & 51.8 & 6.0 & 96.8 & 4.8 & 488.6 & 9.8 \\
\hline $7-10^{\circ}$ & 263.5 & 0.8 & 25.2 & 2.9 & 80.1 & 3.9 & 459.0 & 9.2 \\
\hline $10-15^{\circ}$ & 48.0 & 0.2 & 6.3 & 0.7 & 53.9 & 2.7 & 238.1 & 4.8 \\
\hline$>15^{\circ}$ & 7.7 & - & 1.2 & 0.1 & 27.1 & 1.3 & 74.0 & 1.5 \\
\hline Total & 31655.1 & 100.0 & 866.0 & 100.0 & 2031.5 & 100.0 & 4985.0 & 100.0 \\
\hline
\end{tabular}

Agricultural lands are predominantly located on even lands with a slope angle up to $1^{\circ}$. However, $11.5 \%$ of the arable land (with a slope of $3-5^{\circ}$ and above $5^{\circ}$ ) need to create meadows and forests in these places. Transformation of this area into meadows and forest plantations, that is, ecologically 
sustainable lands, will prevent the erosion processes on them. For this it is necessary to develop projects for the conservation of the particular arable land.

The highest effect of the moisture-saving and anti-erosion measures is achieved under conditions of the contour-meliorative organisation of the territory, which is used on sloping lands with the arrangement of all the linear elements (boundaries of the fields, work sites, field roads) parallel to the field contours [10]. The essence of the contour-meliorative organisation of the territory is to arrange the crop rotations within the plots of arable land with homogeneous ecological conditions, to differentiate between the perennial plantations, hayfields and pastures, depending on the intensity of these areas, and to equip the territory of non-agricultural lands on the principles of ecological balance [14].

Among the agrotechnical measures, which play an important role in fighting erosion, there are phyto-meliorative agronomic measures, agrochemical measures, anti-erosive treatment of soils, fertility increasing and their protection against erosion, achieving erosion resistance of soils. In the context of a contour arrangement of lands, fields and work sites, it is justified to arrange the crops in strips. Widespread use should be made of the treatment across the slope, contour machining and machining to form inclined furrows, non-plough tillage preserving the stubble, i.e. without overturning the layer, flat cutting and chisel tillage. Sowing systems "No-Till" and "Strip-Till" are used.

As it is known, the first task of productive agriculture is maintenance of lumpy soil structure [14]. It can simultaneously provide plants with moisture and nutrients, and therefore it must be kept in proper condition. Due to the fact that the upper layer of the soil gradually loses its useful properties and natural fertility, periodic restoration of the strength of the soil structure belongs to the second most important task of agriculture. The soil structure can be restored only gradually, during several vegetation periods. Since the loss of the soil structure is connected with the upper layer and its restoration by means of the lower layer does not take place, there is virtually no need for ploughing every year. This provision is basic for the introduction of the soil protection systems in agriculture.

Besides, the purpose of such an organisation of the territory is to ensure, in a complex of rational use, reproduction and protection of both the land and the water, as well as the plant resources. This organisation of the territory should facilitate recreation of conditions for the operation of an antierosion complex, close to natural ones, to ensure high water permeability and erosion resistance of soils.

According to the concept of the development of agriculture, approved by the Government of Ukraine in 1990, until 2005, it was intended to introduce anti-erosion measures on an area of 13.9 million hectares of arable land with a slope of more than $1^{\circ}$. In fact, the projects with a contourmeliorative organisation of the territory were developed for 8.2 million hectares of arable land, their elements - boundaries marked in situ, fixed with the appropriate signs, and complexes of anti-erosion works were implemented on a large part of the lands. This provided a possibility to ensure a deficitfree balance of humus in the soil, a positive balance $\left(+21.3 \mathrm{~kg} \cdot \mathrm{ha}^{-1}\right)$ of nutrients (NPK) during the period 1986-1990 in agriculture. For the first time a gross harvest of grain crops of 50 million tons was ensured. In addition to it, up to $148 \mathrm{~kg} \cdot \mathrm{ha}^{-1}$ of the active substance NPK, almost $9.5 \mathrm{t} \cdot \mathrm{ha}^{-1}$ of organic fertilisers were introduced into the soil [12].

In connection with the land reform implemented in the country (since 1991), the organization of the territory on the agricultural land has radically changed. Instead of the previously existing large agricultural enterprises, there are created market-type agrarian structures on the land of the state business partnerships, private-leased enterprises, production cooperatives, farmers' and personal peasants' farms, 27.5 million hectares of agricultural land were divided into land shares and transferred to private ownership of 6.9 million citizens (the area of the share in the country averaged 4.2 hectares). During the reform process the boundaries of the land-use were changed. Attempts were unsuccessful to preserve the anti-erosion boundaries and crop rotations. There was suspended implementation of the anti-erosion measures, especially forest-meliorative and hydrotechnical measures. In addition to private investments, the anti-erosion complex badly needs financial support from the state budget. As a result of this, the area of the eroded land in Ukraine increased to 13.4 million hectares, and that of the arable land - up to 10.6 million hectares (32\% of the total area). The average humus content in the arable layer of soils decreased during the years 1991-2015 from $3.64 \%$ 
to $3.16 \%$ (Fig. 1) [13]. The erosion resistance of soils decreased, but the construction of anti-erosion hydraulic facilities has practically stopped.

Violation of one of the most important laws of agriculture, established in the nineteenth century by the well-known German scientist J. Liebich [17], according to which, in order to preserve the fertility of soils, the farmer is annually obliged to return to the soil that quantity of nutrients taken out from it when harvesting agricultural crops, which causes dehumification of soils and degradation of the soil mantle. Variations in the humus content in the arable layer of soils [16] in three basic soil areals of Ukraine are shown in Fig. 1. During the last 50 years the humus content in the arable layer of the soil in the basic agrarian regions of Ukraine (steppe and forest steppe) has diminished by $15-18 \%$.

Due to the fact that the area of the intertilled, export-oriented crops - sunflower, corn considerably exceeds the permissible standards, erosion and dehumification of soils is intensifying. Because of erosion up to 500 million tons of soil is lost a year in Ukraine. According to expert estimates, there are released about 24 million tons of humus, 0.96 nitrogen, 0.68 phosphorus, and 9.4 potassium [17].

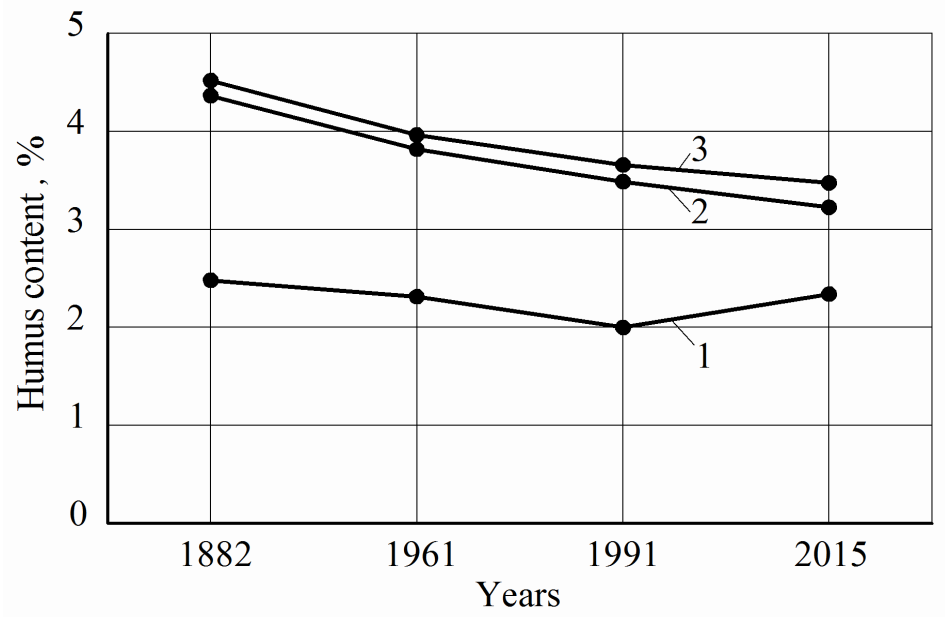

Fig.1. Dynamics of humus content in arable layer of soils in three basic soil areals of Ukraine: 1 - north of Ukraine; 2 - forest steppe (central part); 3 - steppe (southern part)

During the twenty-five-year period, the area of the arable land decreased by 1.03 million hectares (the share of the ploughed territory (i.e. the share of the arable land in the territory) decreased by $3.1 \%$ ), and the area of the ecologically sustainable lands (forests and protective plantations, natural forage lands, water objects, water-swamp territories) increased by 0.94 million hectares (Fig. 2).

When designing the contour-meliorative organisation of a territory, the most important element is differentiation of land by technological groups of use, a justified arrangement both of the land and the crop rotation, and objects of engineering and biological facilities. Each of the types of the agricultural land, depending on the way of its use and peculiarities of the relief, soils, other natural conditions, are divided into three ecological and technological groups. The areas of non-agricultural lands, depending on the specificity of their environmental protection system, are also divided into three groups. Thus, the entire massif of land of each owner, a land user with the right of permanent use or lease, is subject to ecological differentiation [13].

According to the norms that were in force, to the first ecological and technological Group I of arable lands belonged non-eroded and slightly eroded areas of land on slopes up to $3^{\circ}$; to group II mainly medium washed out, partially weakly and strongly washed out, seldom undiluted lands, with a slope of $3-7^{\circ}$; to Group III - lands with a steepness of slopes over $7^{\circ}$. While implementing differentiation of the territory during the development of projects, a careful approach is necessary to the definition of boundaries between the groups of lands, specification of borders between the massifs of owners and users, correcting them, if necessary, and linking them with the relief of the terrain on the land consolidation principles [16]. It is important to establish indicators of the actual intensity of the soil washout [16] and the degree of the soil erosion hazard [17]. 


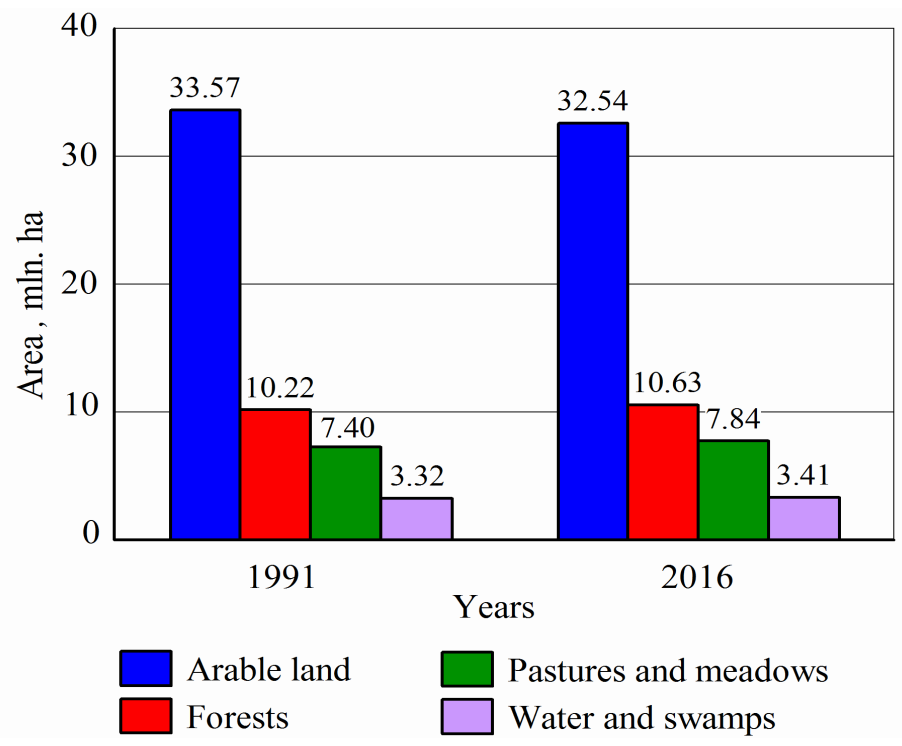

Fig. 2. Dynamics of structure of land in 1991-2016

According to expert estimates, the losses of the agricultural product due to the soil erosion exceed 9-12 million tons of grain units per year. In accordance with the data published by the World Bank in 2014, there are 10 tons of washed-away soil in the agriculture of Ukraine for every ton of grain grown [18]. The most important role in the regulation and preservation of favourable environmental parameters belongs to forest plantations. When designing the contour-meliorative organisation of the territory, in addition to continuous plantations on the slopes, sands, pastures, buffer zones of national parks, nature reserves and wildlife sanctuaries, various types of forest belts were used. Besides, the range of protective actions for different types of forest plantations (in meters) is determined depending on the height of the trees $(\mathrm{H})$, and it is presented in Table 4 [15]. The height of the forest stand $(\mathrm{H})$ is determined depending on the species composition of the forest plantations. Depending on the type and purpose of the plantations, the coefficient, multiplied by the average height of trees of a particular species used in the calculations (the height factor), varies from 10 to 35.

Table 4

Influence of the kind of protective forest plantations upon the distance of their protective action

\begin{tabular}{|l|c|}
\hline \multicolumn{1}{|c|}{ Kind of forest plantations } & $\begin{array}{c}\text { Distance of protective } \\
\text { action of various kinds } \\
\text { of forest plantations, } \mathrm{m}\end{array}$ \\
\hline Forest belts that protect fields & $35 \mathrm{H}$ \\
\hline Forest belts that regulate the flow of water (precipitations) & $25 \mathrm{H}$ \\
\hline Forest belts and plantations along rivers, around water reservoirs, ravines & $15 \mathrm{H}$ \\
\hline Continuous forest plantations (along the perimeter of the fields) & $5-10 \mathrm{H}$ \\
\hline Forest belts along the roads & $30 \mathrm{H}$ \\
\hline
\end{tabular}

An integral part of the complex of anti-erosion measures are hydrotechnical structures designed for complete water runoff detention, or its partial detention and safe removal of that part of the runoff, which cannot be absorbed by the soil. Removal of excessive runoff is carried out by means of chute channels, cascade drops. The bottoms and walls of ravines and gulches are strengthened by dams, retaining walls. Construction of reservoirs for the flow regulation is carried out (dams-estuaries, antierosion ponds). Among the water-detention structures in Ukraine, the most widespread are dams, dams-ditches, dams-terraces characterised by small height $(0.3-0.6 \mathrm{~m})$, slopes that are not steep, with the width of the base allowing unimpeded passage of tractors and other agricultural machines. Being simple earthwork structures, these dams are sufficiently economical. The construction cost of one running meter of a usual dam is 5-10 USD, and of the wall-terrace it is 35-55 USD. The fluctuations in the cost of work within a single region (with the same relief and type of soil) constitute $25 \%$.

The main functions of soils cannot be ensured in cases where there is no control system of the soil formation and phytosynthesis processes, and proper control over the development of the 
degradation processes is not carried out. The creation of joint territorial cooperatives in Ukraine, the transfer of the land management functions to them and the need to optimise the structure of landscapes actualises the need to return to the organisation of the land use by means of the contour-meliorative organisation of the territory.

The solution of the problems of efficient land use, soil protection from degradation is provided by the National Action Plan to Combat Land Degradation and Desertification, adopted by the Government in March 2016 (developed on the basis of the UN Convention). In constructing a system of the contour-meliorative organisation of territories at the present time, one should proceed from the premise that each primary water collection point of the basin should have its own, ecologically motivated structure of elements (the correlation of agricultural areas, forests, natural surface waters, water-swamp areas, non-agricultural lands) ensuring the landscape stability, as a whole. The principle of complex implementation of anti-erosion measures simultaneously across the entire territory of the basin should prevail over the other requirements and options of solution, preventing simplified approaches, especially by differentiating the land use only for the arable land (unfortunately, taking place in practice). It is recommended to divide the second ecologic-technological group (with slopes $3-7^{\circ}$ ) into two independent groups (Group II - from 3 to $5^{\circ}$ and Group III - more than $5^{\circ}$ ). It is proposed to preserve the arable land with slopes over $5^{\circ}$ by laying out meadows and pastures there. There are specified the composition of agrotechnologies and organisation principles of the territory by individual technological groups. Introduction of the contour-meliorative organisation of the territory is now considered in Ukraine also as a factor to be used for the needs of bioenergy of land conservation areas, continuous creation of meadows on the arable land and forests on the sloping lands for the erosion control purposes.

\section{Conclusions}

1. In the system of measures to improve the efficiency of using the land resources, priority is given to ecological optimisation of the structure and proportion of lands in the agrolandscapes, introduction of an adaptive landscape system of the land management with a contour and meliorative organisation of the territory, considering the soil, landscape and climatic factors.

2. The highest effect of moisture-saving and anti-erosion measures is achieved under conditions of the contour-meliorative organisation of the territory.

3. An improved model for the formation of agrolandscapes and differentiation of the land use for all types of land is recommended. The object of formation of this system should be the primary water collectors.

\section{References}

[1] Barwicki J., Gach S., Ivanovs S. Proper utilization of soil structure for crops today and conservation for future generations. Engineering for Rural Development. Proceedings of 11th International Scientific Conference, Volume 11, 2012, pp.10-15

[2] Voloshchuk M., Petrenko N., Yatsenko S. Erosion of soils of Ukraine: the evolution of theory and practice. A monograph, 2014, Kiev: 325 p. (In Ukrainian).

[3] Каштанов А., Заславский М. Почвоохранное земледелие (Conservation Agriculture), Rosselkhozizdat, Moscow. 1984. 462 p. (In Russian)

[4] Моргун Ф., Шикула Н., Тарарико А. (1983), Почвозащитное земледелие (Soil-protecting agriculture), Kiev, 1983, 240 p. (In Ukrainian)

[5] Швебс Г. Теоретичесие основы эрозиоведения (Theoretical foundations of erosion). Odessa, 1981, 224 p. (In Ukrainian)

[6] Morgan R.P.C. Soil Erosion and Conservation - 3rd ed., National Soil Resources Institute, Cranfield University, 2005, $316 \mathrm{p}$.

[7] Blaikie P.M. The Political Economy of Soil Erosion in Developing Countries, Longman, London, 2000, $188 \mathrm{p}$.

[8] Bakker M., Govers G., Doorn A., Quetier F., Chouvardas D., Rounsevell M. The response of soil erosion and sediment export to land-use change in fourareas of Europe», The importance of land scapepattern, Volume 98, No. 3-4, 2008, pp. 213-226. 
[9] Lance D. Yarbrough. Use of Revised Universal Soil Loss Equation (RUSLE) and Historical Imagery for Claims of Sedimentation of Lakes and Streams. Environmental Forensics, Vol.15 (3), 2014, pp. 244-256.

[10] John M. Laflen, Dennis C.Flanagan,, Soil erosion prediction and modelling. International Soil and Water Conservation Research, Volume 1, No. 2, 2013, pp. 1-11.

[11] Tarariko A., Ilyenko T., Kuchma T. Formation of sustainable agro-landscapes in conditions of climate change, Agroecological Journal, No. 4, 2013, pp. 13-20.

[12] Novakovsky L., Novakovska I. Ecological and legal problems of protection of lands. News of agrarian science, No. 11, 2017, pp. 61-70.

[13] Tarariko O., Kuchma T., Ilienko T., Demyanyuk O. Soil erosion degradation of Ukraine under the impact of climate chanqe», Agroecological Journal, No. 1, 2017, pp. 7-15

[14] Adamchuk, V., Bulgakov, V., Tanchyk, S., Nadykto, V. Modem problems of ploughing as special method of soil cultivation. News of agrarian sciences, No. 1, 2016, pp. 5-10.

[15]Каштанова А. Методическое пособие и нормативные материалы для разработки адаптивноландшафтной системы земледелия (Methodical manual and normative materials for the development of adaptive-landscape system of agriculture), Tver, 2001. 260 p. (In Russian)

[16] Тарарико А., Лобас М. Нормативы грунтозащитных систем земледелия (Standards of soil protection contour-reclamation systems of agriculture), Kiev, 1998, 158 p. (In Ukrainian).

[17] Baliuk S., Nosko B., Skrylnyk Y. Modem problems of biological degradation of black earth and ways of preserving their fertility, News of agrarian sciences, No 1, 2016, pp. 11-17.

[18] Shevchenko I., Kolomiets L., Kravets S., Shkvyr I. Optimization of agro-landscapes systems as a basis for sustainable development of agriculture. Agriculture, Issue 2. 2015. pp. 31-37. 